Jurnal Inkofar * Volume 1 No. 2, Desember 2018 * ISSN: 2615-3645 (Print) / 2581-2920 (Online)

Tersedia secara online di: http://www.politeknikmeta.ac.id/meta/ojs/

\title{
PENGEMBANGAN SISTEM PEMBAYARAN MAHASISWA DENGAN MOBILE PAYMENT BTN SYARIAH
}

\author{
Eko Purwanto ${ }^{1}$, Sopingi ${ }^{2}$ \\ ${ }^{1}$ Teknik Informatika / Ilmu Komputer / Universitas Duta Bangsa / eko_purwanto@udb.ac.id \\ ${ }^{2}$ Sistem Informasi / Ilmu Komputer / Universitas Duta Bangsa / sopingi@udb.ac.id
}

\begin{abstract}
The development of student payment information system at STMIK Duta Bangsa or Duta Bangsa University especially at the Faculty of Computer Science was also conducted in collaboration with Bank BTN Syariah in an effort to improve services to students, especially student payment services. This study uses a prototype method in system development. System development includes Infrastructure Design and Payment system implementation with BTN Syariah mobile payments. The results in this study were obtained in the development of student payment systems with BTN Syariah mobile payments by adding a Cloud Server as an integration or link between a local server and BTN Syariah. The implementation of the mobile payment system has run well.
\end{abstract}

Keywords : Development, System, Mobile, Payment, Prototipe, Intagration

\begin{abstract}
ABSTRAK
Pengembangan sistem informasi pembayaran mahasiswa pada Universitas Duta Bangsa Surakarta khususnya pada Fakultas Ilmu Komputer juga dilakukan dengan bekerjasama dengan Bank BTN Syariah dalam upaya peningkatan pelayanan kepada mahasiswa khususnya pelayanan pembayaran mahasiswa. Penelitian ini menggunakan metode prototype dalam pengembangan sistem. Pengembangan sistem meliputi Perancangan Infrastrutur dan Implementasi sistem pembayaran dengan mobile payment BTN Syariah. Hasil dalam penelitian ini yang didapatkan adalah dalam pengembangan sistem pembayaran mahasiswa dengan mobile payment BTN Syariah dengan cara menambahkan Server Cloud sebagai integrasi atau penghubung antara server local dengan BTN Syariah. Implementasi sistem mobile payment sudah dapat berjalan dengan baik.
\end{abstract}

Kata Kunci : pengembangan, sistem, mobile, payment, prototype, integrasi

\section{PENDAHULUAN}

STMIK Duta Bangsa Surakarta yang sekarang menjadi Universitas Duta Bangsa merupakan salah satu perguruan tinggi swasta dengan memiliki empat fakultas. Fakultas Ilmu Komputer merupakan salah satu fakultas di Universitas Duta Bangsa memiliki jenjang pendidikan Strata Satu (S1) dan Diploma Tiga (D3). Sistem informasi pembayaran mahasiswa yang ada awalnya masih single user belum dapat memberikan informasi kepada berbagai pihak yang berkepentingan seperti rektor, dekan, bagian akademik, bagian pendaftaran dan mahasiswa. Dengan meningkatnya jumlah mahasiswa maka pelayanan terhadap mahasiswa khususnya pelayanan pembayaran mahasiswa dirasa masih perlu diperbaiki, agar pelayanan kepada mahasiswa efektif dan efisien. Pengembangan sistem informasi pembayaran mahasiswa pada Universitas Duta Bangsa Surakarta khususnya pada Fakultas Ilmu Komputer juga dilakukan dengan bekerjasama dengan Bank BTN Syariah dalam upaya peningkatan pelayanan kepada mahasiswa khususnya pelayanan pembayaran mahasiswa.

Universitas Duta Bangsa Surakarta sudah memiliki infrastruktur jaringan baik local maupun WAN atau internet. Berdasarkan dari maslah tersebut penulis bermaksud untuk 
Jurnal Inkofar * Volume 1 No. 2, Desember 2018 * ISSN: 2615-3645 (Print) / 2581-2920 (Online)

Tersedia secara online di: http://www.politeknikmeta.ac.id/meta/ojs/

mengembangkan Sistem Pembayaran Mahasiswa pada STMIK Duta Bangsa atau Universitas Duta Bangsa dengan melakukan integrasi sistem dengan sistem mobile payment pada Bank BTN Syariah, sehingga dengan integrasi sistem tersebut diharapkan mampu membantu Universitas Duta Bangsa Surakarta dan Bank BTN Syariah dalam melayani mahasiswa terhadap proses pembayaran pendidikan.

\section{STUDI PUSTAKA}

Proses Pengembangan Sistem Pembayaran Mahasiswa di APIKES Citra Medika dengan cara mengintegrasikan antara Sistem Pembayaran Mahasiswa pada APIKES Citra Medika dengan Sistem Kas Masuk Bank BPD Jateng Syariah dengan menggunakan database Biller sebagai penghubung antara sistem Pembayaran Mahasiswa di APIKES Citra Medika dengan Sistem Kas Masuk di Bank PBD Jateng Syariah. Model Integrasi Sistem dijembatani dengan Server Biller yang berada diantara Router Bank BPD Jateng Syariah dan Router APIKES untuk menjaga keamanan masing-masing data pada kedua sistem baik sistem Bank BPD Jateng Syariah dan sistem Pembayaran Mahasiswa APIKES Citra Medika.Integrasi Sistem dapat memberikan informasi yang real time baik informasi tagihan mahasiswa maupun informasi pembayaran mahasiswa yang telah dilakukan di Bank BPD Jateng Syariah (Purwanto, 2015)

Model integrasi sistem Host to Host atau $\mathrm{H} 2 \mathrm{H}$ yang telah diterapkan antara Politeknik Indonusa dengan Bank BRI Syariah. Politeknik Indonusa Surakarta telah menjalin kerjasama dengan Bank BRI Syariah dalam hal pelayanan terhadap pembayaran pendidikan, dengan model integrasi sistem Host to Host sistem atau $\mathrm{H} 2 \mathrm{H}$ dapat meningkatkan pelayanan kepada mahasiswa.. Untuk menjaga keamanan sistem dan data yang ada di Politeknik Indonusa Surakarta dan sistem di Bank BRI Syariah maka dengan model Host to Host sistem ini dengan dijembatani sebuah sever biller yang pakai sebagai sarana untuk menampung data tagihan dan data transaksi mahasiswa yang dilakukan di Bank. Pengembangan sistem ini dimaksudkan untuk meningkatkan pelayanan Politeknik Indonusa Surakarta dalam melayani pembayaran kepada mahasiswa yang dapat dilakukan di Bank BRI Syariah baik melalui Anjungan Tunai Mandiri atau ATM serta melalui e- Banking atau Anjungan Tunai Mandiri mini yang ada di Politeknik Indonusa Surakarta (Purwanto, 2016). SOAP dan REST sebagai alat untuk melakukan uji kinerja sistem dari sistem web service yang telah dibangun. Dengan menggunakan metode SOAP dan REST untuk mendapatkan informasi dari keuda metode tersebutpeneliti telah melakukan proses uji kinerja dari sistem web service yang telah dibangun dengan menggunakan SOAP dan REST sebagai cara untuk memperoleh informasi untuk mendapatkan pengetahuan alat atau cara yang mana yang tepat dan baik kinerjanya sebagai bahan pertimbangan dalam penerapan integrasi sistem yaitu sistem pembayaran mahasiswa yang ada di Universitas AMIKOM Yogyakarta. Alat yang digunakan dalam melakukan uji kinerja sistem adalah memakai alat Apache JMeter. Berdasarkan hasil dari penelitian tersebut didaptkan bahwa dengan SOAP atau Response Time dari sistem kinerjanya menunjukkan lebiah cepat dibandingkan dengan prototype dari sistem baru atau REST (Kamarudin, Kusrini and Sunyoto, 2018).

Teknologi perbankan telah mengalami perkembangan salah satunya yang telah dirilis adalah teknologi sistem pembayaran dengan menerapkan model Host to Host sistem atau $(\mathrm{H} 2 \mathrm{H})$, model sistem Host to Host $(\mathrm{H} 2 \mathrm{H})$ yang saat ini berkembang dengan dihubungkan dengan melalui koneksi internet yang terhubung dengan server atau host yang ada dalam institusi maka semua request atau permintaan layanan transaksi kepada bank dapat dilayani secara cepat dan tepat waktu. Salah satu institusi yang dapat memanfaatkan $\mathrm{H} 2 \mathrm{H}$ antara lain perguruan tinggi terkait aktivitas pembayaran yang dilakukan mahasiswa. Namun $\mathrm{H} 2 \mathrm{H}$ harus dijembatani sebuah interface/aplikasi yang berfungsi sebagai web services yang tentunya mempermudah dalam melakukan komunikasi dengan $\mathrm{H} 2 \mathrm{H}$ (Pradesan, 2017).

Proses pembayaran tunai digantikan dengan pembayaran elektronik. Mengenai keamanan 
Jurnal Inkofar * Volume 1 No. 2, Desember 2018 * ISSN: 2615-3645 (Print) / 2581-2920 (Online)

Tersedia secara online di: http://www.politeknikmeta.ac.id/meta/ojs/

dalam proses pembayaran secara elektronik menjadi permasalahan tersendiri dan harus diperhatikan. Untuk menjaga keamanan pembayaran secara elektronik dikembangkan suatu teknologi pure-based micro payment system. Model sistem ini merupakan suatu sistem prabayar yang mana uang disimpan dalam chip ponsel. Teknologi Near Field Communication atau disebut teknologi NFC dapat digunakan untuk membantu proses transaksi yang dilakukan secara contactless dengan sistem point of sale atau POS. pengisian chip tersebut atau proses isi ulang dari chip tersebut dapat dilakukan melalui transaksi pada over the air atau disebut OTA yang dapat dilakukan dimana saja dan kapan saja atau juga dapat dilakukan melalui Anjungan Tunai Mandiri atau ATM (Yesmaya and Darmawan, 2013).

Mobile Payment atau M-Payment merupakan suat cara yang digunakan untuk proses transaksi pembayaran dengan menggunakan mobile phone atau ponsel. Sekarang ini banyak perbankan yang menggunak produk moble payment ini seperti Mobile Banking atau MBanking, dengan melalui aplikasi MBanking ini nasabah dapat melakkan cek saldo rekening, transfer uang, pembayaran tagihan dan pembelian pulsa isi ulang (Irianto, 2011).

\section{HASIL, ANALISA DAN PEMBAHASAN}

\subsection{Metode Pengumpulan Data}

a. Wawancara

Penulis melakukan pengumpulan data dengan melakukan wawaancara kepada stake holder terkait dengan pengembangan sistem pembayaran mahasiswa ini. Wawancara untuk mengumpulkan data yang meliputi data proses pembayaran mahasiswa, data taagihan pembayaran mahasiswa dan data prosess pembayaran mahasiswa melalui bank yang sudah bekerja sama dengan STMIK Duta Bangsa.

b. Observasi

Penulis melakukan observasi terkait dengan Proses Pembayaran Mahasiswa yang dilakukan melakui bank yang sudah bekerja sama dengan STMIK Duta Bangsa.

\subsection{Pengembangan Sistem}

Proses pengembangan sistem ini menerapkan cara pengembangan sistem prototipe. Adapun tahapan dalam pengemabngan sistem prototype ini antara lain ${ }^{[8]}$ :

a. Mendengarkan pelanggan

Pada tahap ini penulis menggali informasi mengenai proses transaksi penagihan, transaksi pembayaran yang dilakukan oleh bagian keuangan dan mahasiswa yang ada di STMIK Duta Bangsa yang sekarang menjadi Universitas Duta Bangsa yang bekerja sama dengan Bank BTN Syariah Surakarta. Informasi yang didapatkan digunakan untuk mengembangkan Sistem Pembayaran Mahasiswa dengan menggunakan mobile payment BTN Syariah..

b. Membangun memperbaiki prototype

Pada tahap membangun memperbaiki prototype ini penulis mendesain sistem sesuai dengan kebutuhan pelanggan yaitu antara STMIK Duta Bangsa atau Universitas Duta Bangsa dengan Bank BTN Syariah Surakarta. Pada tahapan ini meliputi: mendesain infrastruktur sistem dan desain model dari mobile payment yang akan digunakan.

c. Pengujian prototype

Pada tahapan ini penulis akan melakukan pengujian sistem yang telah dirancang dan dikodekan dengan pengujian Black box dan pengujian ke pengguna penulis mengevaluasi terhadap sistem untuk mendapatkan hasil sistem sesuai dengan yang diharapkan oleh pelanggan. 
Jurnal Inkofar * Volume 1 No. 2, Desember 2018 * ISSN: 2615-3645 (Print) / 2581-2920 (Online)

Tersedia secara online di: http://www.politeknikmeta.ac.id/meta/ojs/

\subsection{Analisa Masalah}

Model sistem yang sedang berjalan seperti Gambar 1 berikut ini :

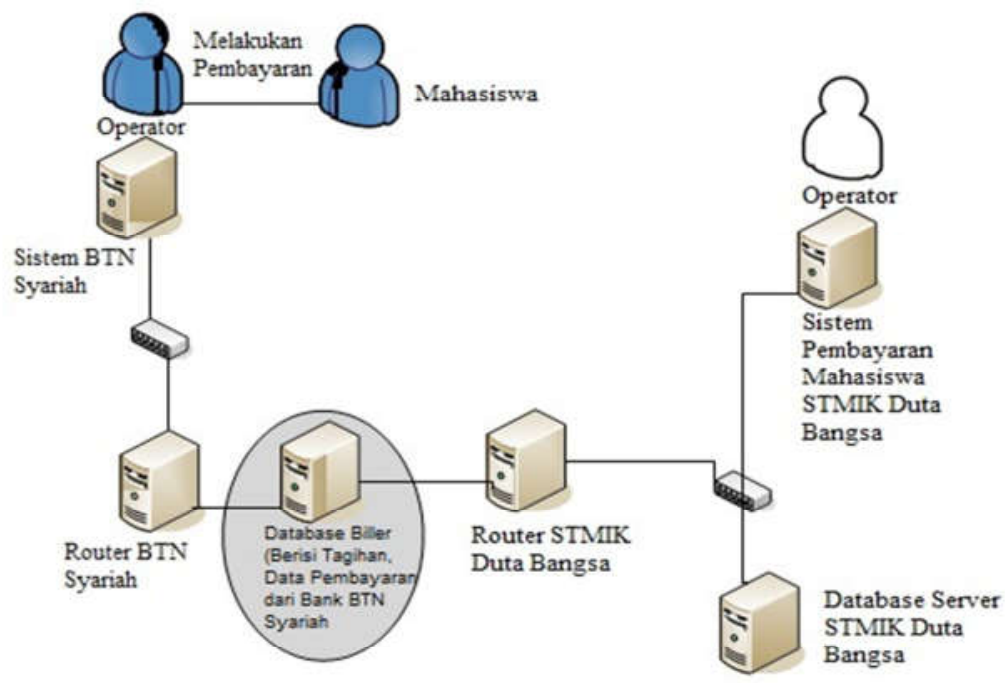

\section{Gambar 1. Model Integrasi Sistem antara STMIK Duta Bangsa atau Universitas Duta Bangsa dengan Bank BTN Syariah yang berjalan}

Pada gambar di atas bahwa model integrasi yang berjalan antara STMIK Duta Bangsa atau Universitas Duta Bangsa dengan Bank BTN Syariah adalah dengan menambahkan Database Server Biller yang berfungsi untuk menampung data tagihan yang dikirimkan dari Sistem Informasi Pembayaran Mahasiswa STMIK Duta Bangsa atau universitas Duta Bangsa yang akan digunakan oleh BTN Syariah dalam menerima Pembayaran Mahasiswa sesuai dengan tagihan yang telah dikirimkan oleh Sistem Pembayaran Mahasiswa yang ada di STMIK Duta Bangsa. Setelah mahasiswa membayar tagihan melalui Bank BTN Syariah maka data pembayaran akan ditampung pada Database Biller kemudian Sistem Informasi Pembayaran Mahasiswa akan mengambil data transaksi tersebut sebagai laporan kas harian maupun pembayaran mahasiswa kepada pimpinan.

\subsection{Merancang Prototype}

Merancang suatu aplikasi meliputi perancangan infrastruktur sistem, Implementasi sistem.

\subsubsection{Perancangan Infrastruktur Sistem}

Perancangan infarstruktur sistem merupakan pengembangan dari infrastruktur yang sudah ada dan sudah berjalan antara STMIK Duta Bangsa atau Universitas Dta Bangsa dengan Bank BTN Syariah. Perancangan Infrastruktur yang dikembangkan terlihat seperti pada gambar 2 berikut ini : 
Jurnal Inkofar * Volume 1 No. 2, Desember 2018 * ISSN: 2615-3645 (Print) / 2581-2920 (Online)

Tersedia secara online di: http://www.politeknikmeta.ac.id/meta/ojs/

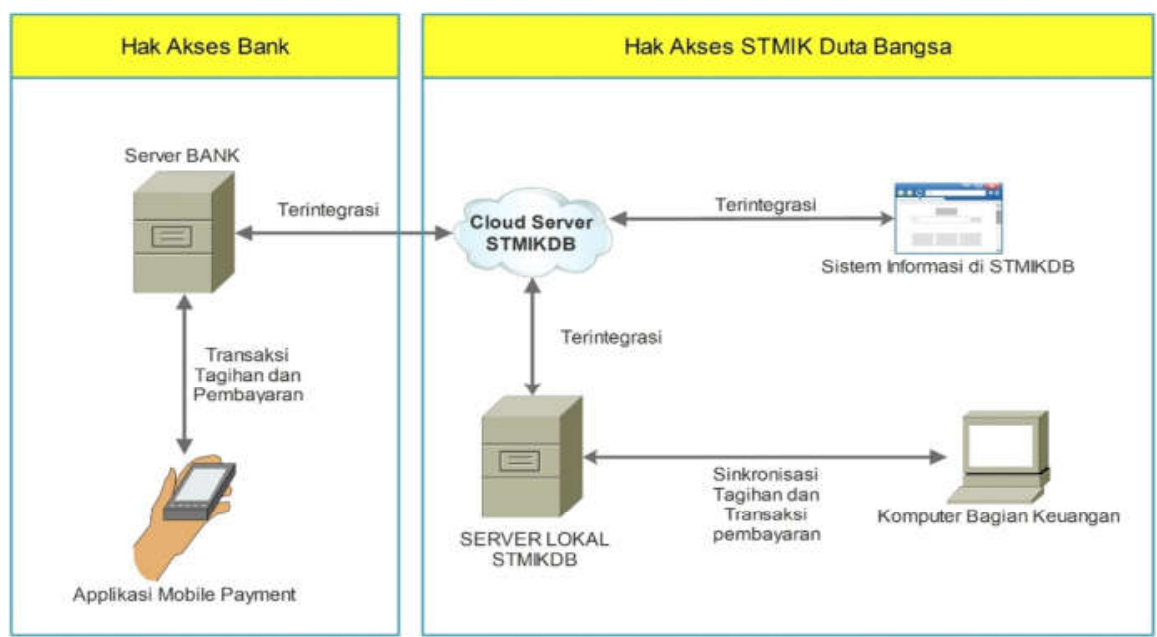

\section{Gambar 2. Model Pengembangan Integrasi Sistem antara STMIK Duta Bangsa atau Universitas Duta Bangsa dengan Bank BTN Syariah dengan Mobile \\ Payment}

Pada gambar di atas bahwa model pengembangan integrasi yang berjalan antara STMIK Duta Bangsa atau Universitas Duta Bangsa dengan Bank BTN Syariah adalah dengan mengganti Database Server Biller diganti dengan Cloud Server yang berfungsi untuk menampung data tagihan yang dikirimkan dari Sistem Informasi Pembayaran Mahasiswa STMIK Duta Bangsa atau universitas Duta Bangsa yang akan digunakan oleh BTN Syariah dalam menerima Pembayaran Mahasiswa melalui Aplikasi Mobile Payment sesuai dengan tagihan yang telah dikirimkan oleh Sistem Pembayaran Mahasiswa yang ada di STMIK Duta Bangsa. Setelah mahasiswa melakukan pembayaran tagihan baik melalui Bank BTN Syariah, transfer lewat ATM atau Mobile Banking maka data pembayaran akan ditampung pada Cloud Server kemudiaan Server Local STMIK Duta Bangsa akan melakukan Sinkronisasi terhadap Cloud Server secara otomatis dan Real Time sehingga Sistem Informasi Pembayaran Mahasiswa akaan secara otomatis dan real time mengambil data transaksi tersebut sebagai laporan kas harian maupun pembayaran mahasiswa kepada pimpinan.

\subsubsection{Implementasi Sistem}

Implementasi sistem merupakan implementasi tagihan pembayaran mahasiswa sampai proses pembayaran dengan mobile payment.

a. Form Transaksi Tagihan Mahasiswa

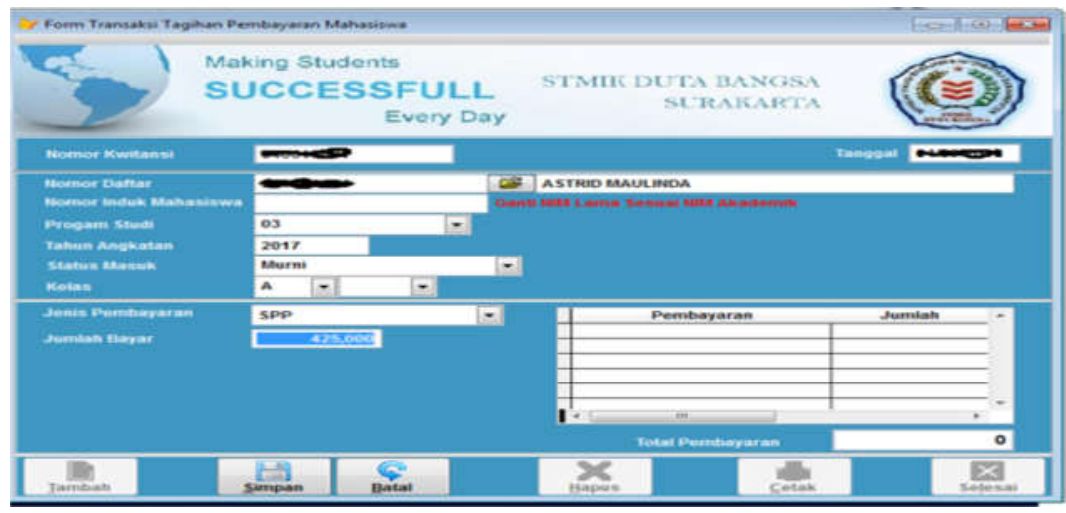

Gambar 3. Proses Transaksi Tagihan Mahasiswa 
Jurnal Inkofar * Volume 1 No. 2, Desember 2018 * ISSN: 2615-3645 (Print) / 2581-2920 (Online)

Tersedia secara online di: http://www.politeknikmeta.ac.id/meta/ojs/

Kererangan :

Form di atas merupakan form yang diperuntukan untuk melakukan penagihan pembayaran mahasiswa yang dilakukan oleh bagian keuangan. Cara menjalankan form ini adalah setelah periode tertentu dan mahasiswa diwajibkan membayar biaya pendidikan yang telah ditentukan misalkan SPP, ujian dsb maka maka bagian pembayaran atau admin melakukan tagihan pembayaran mahasiswa sesuai yang dinginkan pada salah satu mahasiswa yang nanti tagihan akan dikirim ke database server local yang terintegrasi dengan Cloud Server yang nantinya akan digunakan oleh BTN Syariah dalam proses transaksi pembayaran mahasiswa.

b. Aplikasi Mobile Payment BTN Syariah

Download aplikasi Mobile Payement BTN Syariah pada Play Store seperti gambar 4 berikut ini :

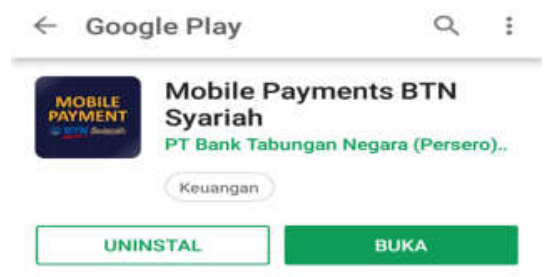

\section{Gambar 4. Download aplikasi Mobile Payement BTN Syariah}

c. Log In Aplikasi Mobile Payment BTN Syariah

Untuk dapat log In aplikasi Mobile Payment BTN Syariah masukan Username dengan mengisikan alamat e-mail yang anda miliki serta masukan password email tersebut seperti pada gambar 5 berikut ini :

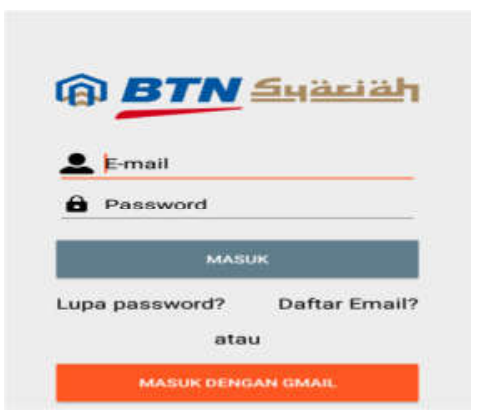

Gambar 5. Log In Aplikasi Mobile Payement BTN Syariah

d. Halaman Home Aplikasi Mobile Payment BTN Syariah

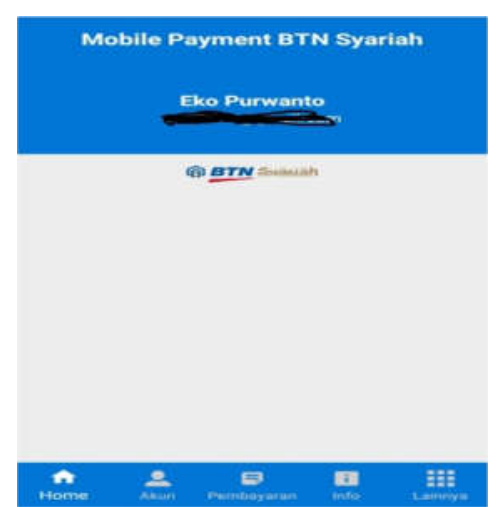

Gambar 6. Halaman Home Aplikasi Mobile Payement BTN Syariah 
e. Halaman Tambah Akun Pembayaran

Untuk dapat mendapatkan akun pembayaran mahasiswa pilih menu Akun pada halaman Home, kemudian isikankode lembaga dan id pembayaran yang telah didapatkan dari kampus seperti gambar 6 berikut ini :

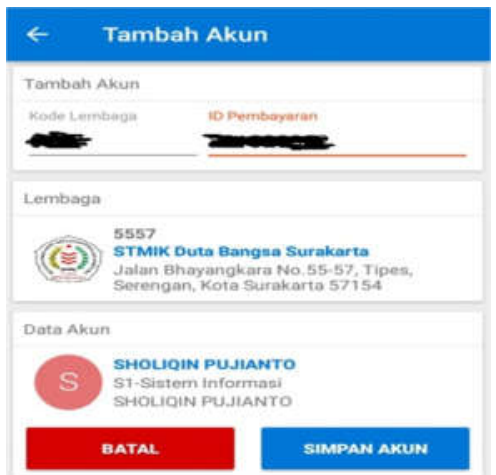

\section{Gambar 7. Tambah Akun Pembayaran Aplikasi Mobile Payement BTN Syariah}

f. Halaman akun pembayaran mahasiswa

Halaman akun pembayaran mahasiswa berisi menu Tagihan, menu History dan Menu Hapus seperti pada 8 berikut ini :

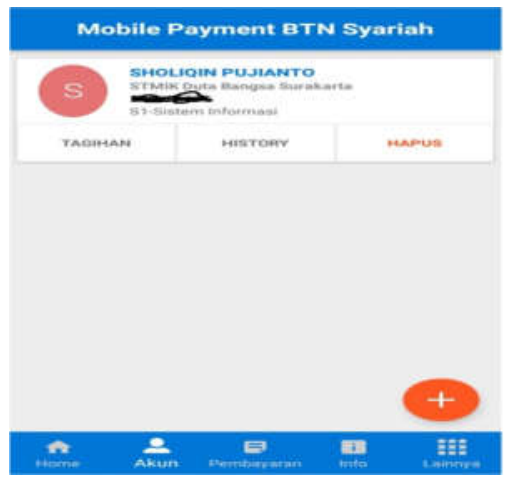

Gambar 8. Halaman Akun Pembayaran Aplikasi Mobile Payement BTN Syariah

g. Halaman Tagihan Pembayaran Mahasiswa

Halaman Tagihan Pembayaran Mahasiswa berisi tagihan pembayaran mahasiswa yang harus dibayar seperti pada gambar 9 berikut ini :

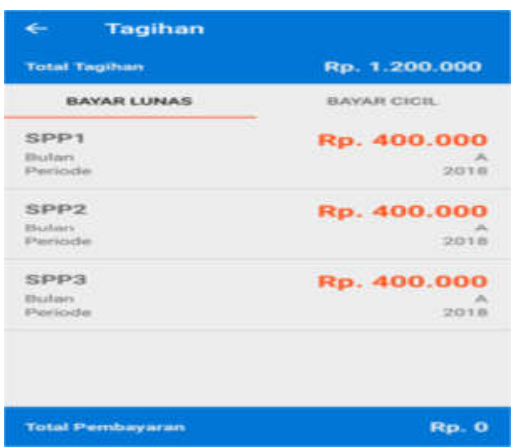

\section{Gambar 9. Halaman Tagihan Pembayaran Aplikasi Mobile Payement BTN} Syariah 
Jurnal Inkofar * Volume 1 No. 2, Desember 2018 * ISSN: 2615-3645 (Print) / 2581-2920 (Online)

Tersedia secara online di: http://www.politeknikmeta.ac.id/meta/ojs/

h. Pembayaran Mahasiswa

Untuk dapat melakukan pembayaran maka mahasiswa harus membuka halaman tagihan pembayaran kemudian memilih tagihan pembayyaran yang akan dibayar dengan cara digeser seperti gambar 10 berikut :

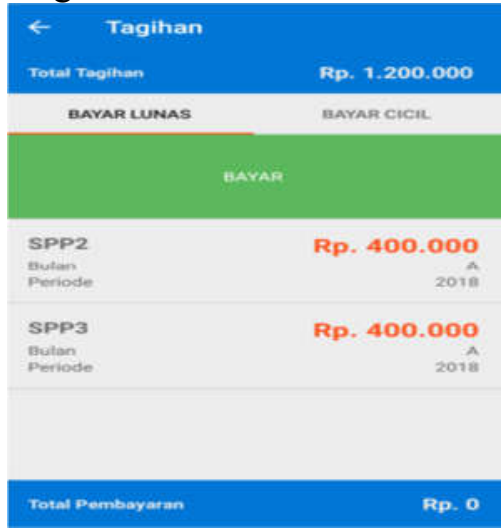

\section{Gambar 10. Halaman Pembayaran Tagihan Pembayaran Aplikasi Mobile} Payement BTN Syariah

Setelah melakukan transaksi tagihan pembayaran maka mahasiswa diberi waktu selama dua jam untuk melakukan pembayaran melalui Bank BTN Syariah, ATM atau Mobile Banking dengan menunjukan no Virtual Account seperti pada gambar 11 berikut ini :

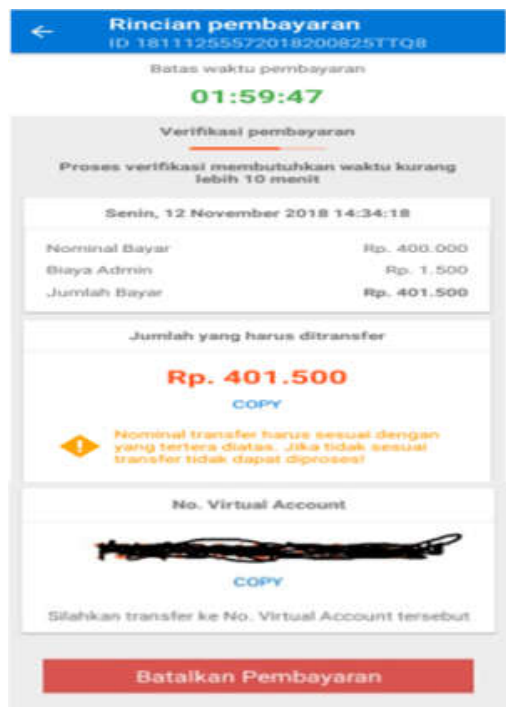

\section{Gambar 11. Nomor Virtual Account Pembayaran Mahasiswa}

\section{KESIMPULAN}

Berdasarkan hasil pembahasan penulis menarik kesimpulan seperti berikut :

a. Pengembangan Sistem Pembayaran Mahasiswa dengan Mobile Payment BTN Syariah dengan menambahkan server cloud yang menjadi jembatan antara server local dengan server Mobile Payment BTN Syariah.

b. Pengembangan Sistem Pembayaran Mahasiswa dengan Mobile Payment BTN Syariah dapat mempermudah bagi mahasiswa dalam melakukan transaksi pembayaran dan membantu bagian keuangan STMIK Duta Bangsa Surakarta dalam melakukan tagihan pembayaran kepada mahasiswa. 
Jurnal Inkofar * Volume 1 No. 2, Desember 2018 * ISSN: 2615-3645 (Print) / 2581-2920 (Online)

Tersedia secara online di: http://www.politeknikmeta.ac.id/meta/ojs/

c. Pengembangan Sistem Pembayaran Mahasiswa dengan Mobile Payment BTN Syariah dapat meningkatkan kerjasama antara STMIK Duuta Bangsa atau Universitas Duta Bangsa dengan Bank BTN Syariah Cabang Surakarta.

\section{UCAPAN TERIMAKASIH}

Penulis mengucapkan terimakasih kepada STMIK Duta Bagsa yang sekarang menjadi Universitas Duta Bangsa yang sudah memberikan dukungan terhadap penelitian ini serta penulis juga mengucapkan terimakasih kepada Bank BTN Syariah yang telah bekerjasama dengan baik sehingga penelitian penulis dapat terlaksana dengan baik.

\section{DAFTAR PUSTAKA}

Irianto, A. (2011) Mengenal Mobile Payment, Cara Pembayaran Masa Depan, Plimbi. Available at: http://www.plimbi.com/review/1063/mobile-payment (Accessed: 10 November 2018).

Pradesan, I. (2017) 'Perancangan dan Implementasi Sistem Informasi Pembayaran pada Perguruan Tinggi Menggunakan Web Services Metode H2H dari Perbankan', 4(1), pp. 101112.

Purwanto, E. (2015) 'Desain Model Integrasi Sistem Informasi Pembayaran Mahasiswa APIKES Citra Medika Surakarta Dengan Sistem Kas Masuk Pada Bank BPD Jateng Syariah', Jurnal Ilmiah Teknologi Informasi Dan Komunikasi Duta.Com, 8(2), pp. 3-12. Available at: http://journal.stmikdb.ac.id/index.php/dutacom/article/view/19/18.

Purwanto, E. (2016) 'Integrasi Sistem Pembayaran Mahasiswa Politeknik Indonusa Surakarta Dengan Bank Rakyat Indonesia (BRI) Syariah Dengan Host to Host System', Informa, 3(2), pp. 13-17. Available at: http://www.poltekindonusa.ac.id/wpcontent/uploads/2017/01/5-eko-purwanto.pdf.

Sunyoto, A. (2018) 'Uji Kinerja Sistem Web Service Pembayaran Mahasiswa Menggunakan Apache JMeter ( Studi Kasus : Universitas AMIKOM Yogyakarta )', XIII, pp. 44-52.

Yesmaya, V. and Darmawan, D. (2013) 'Implementasi NFC sebagai media untuk transaksi pembayaran berbasis mobile', Jurnal Teknik dan Ilmu Komputer, 2(7), pp. 280-286. 